\title{
Blasts 9 Percent or Less of Peripheral Blood White Cells
}

National Cancer Institute

\section{Source}

National Cancer Institute. Blasts 9 Percent or Less of Peripheral Blood White Cells. NCI

Thesaurus. Code C153120.

A semi-quantitative microscopic finding indicating that 9 percent or less of the nucleated cells in a peripheral leukocyte sample are immature mononuclear cells. 